\title{
Collaborative Protection of Rohingya's Muslim Asylum Seekers in North Aceh
}

\author{
Khamami Zada \\ State Islamic University (UIN) Syarif Hidayatullah \\ Jakarta \\ khamami@uinjkt.ac.id
}

\begin{abstract}
Refugee and asylum seekers recently have been global issues. They usually are minorities stateless that escape oppression from their country. Having arrived in the host country, they will face many problems such as settlements, logistics, health, and education. They need any protections based on international law principles. Yet, many countries do not have any capacities to provide their rights as refugees and asylum seekers. This study analyzes the Indonesian government's protection policy for Rohingya's Muslim asylum seekers in North Aceh. By investigating political policy, the study found that Indonesian government respects to the international refugee law principles to protect themto receive freedoms enabling them to live well-protected. This protection has been significantly determined by the collaboration of Indonesian government policy with international organisation and Indonesian civil society. This study suggests that Indonesian government should propose a comprehensive solution for granting them to live well based on international human rights principles.
\end{abstract}

Keywords-Refugee and asylum seekers; Rohinya; collaborative protection; interntaional law.

\section{INTRODUCTION}

Minorities are persecuted in many countries that make them escape from oppression in order to survive in foreign country (Lewa, 2009:11). Having arrived in another country, they are powerless in every situation (Grønlund, 2016) so that they need any protections as refugees. Their needs include not only logistics, but also health protection against waterborne illness and lack of obstetric care (Nishiura, Lee, Yuan, Endo, Akhmetzhanov, Chowell, 2017: 20; Mahmood, Wroe, Fuller, Leaning, 2017:1841). They as new comers also need employment as a key strategy to ensure long term integration (Pajic, Ulceluse, Kismihók, Mol, den Hartog, 2017), and human rights aspects of citizenship and migration (Kampan, Tanielian, 2017: 233). In the host countries, the refugee crisis becomes a potential threat to internal stability (Rahman, 2010) or security implications (Askali, 2016) which can be solved by bilateral negotiations accelerated by the concerted efforts of the local and international communities (Parnini, 2013). Morever, these people were forced to be repatriated due to the fact that the host countries cannot afford their primary needs (Ullah, 2011).
Rohingya people are refugees that recently face some problems after they have escaped from state-sponsored persecution. By investigating experiences of Rohingya who stayed in the second half of May 2015 in North Aceh, Indonesia, this paper discusses policies for refugee protection in Indonesian government characterized by the implementation of international refugee law principles and collaborative mechanism.

Graham Thom (2015) argues that the current situation in Aceh is not sustainable. So, refugees need certain protection strategies and own mechanisms. The treatment of refugees in Aceh should be included in a broader national approach developed as rights-based approach. While Samuel Cheung (2012:50) proposes that the intermediate solutions which capitalize migration management and refugee protection and empower refugee-driven solutions in all dimensions is significant. Yet, Indonesia ironically does not have legislation that provides for the granting of asylum or refugee status in accordance with the 1951 UN Convention relating to the Status of Refugees and its 1967 protocol. Newertheless, Indonesia have political will for granting asylum seekers and refugees which generally is supported by national and local policies or regulations. Therefore, Indonesia has the intermediate solutions for them.

\section{SETTLEMENT IN ACEH}

The Rohingyas, who were made stateless by the Myanmar government in the 1970 s, initially fled to Bangladesh. In the 1980s they started arriving in Malaysia and were given temporary protection (Kaur, 2007: 87). In 2015, they were forced to flee their country for the sake of survival. Since Malaysia was the favoured destination for refugees in the current crisis, they still arrived in Malaysia. Malaysia attracts them to come because it is a Muslim country and provides employment opportunities for low-skilled labour (Lim, 2015). They think if they migrate to Malaysia, they will be able to get jobs like their brothers who have been living there for years. In addition, the same identity between the Rohingya and Malaysian make them feel secured and comfortable. They will not be treated unfairly by the people and the Malaysian government. They believe that they will get good treatment and better jobs there. Nevertheless, there are also a few of them who only transit here and prefer to Australia as their 
final destination (an interview with a Rohingya refugee, 2015). They also can reunite with their relatives and family reunion is one of the most important things in their life.

Nevertheless, the long and tiresome journey by boats from Myanmar and arriving in Aceh not their preferred destination did not make them frustrated. After turbulence in the sea, they finally landed in Aceh. Initially they were rejected by the Indonesian Army, that blocked them to enter Indonesian territory. However, Acehnese fishermen eventually helped them to land and stay. They were 310 people consisting of 202 male persons and 108 female persons. They were placed in Kuala Cangkoi for one month and then moved to a sports center in Lhok Sukon, North Aceh for two days. Afterwards, they were moved to a jobs training centre in North Aceh. Currently, shelters for them were built in Blang Ado, North Aceh. In the shelters, adequate facilities were provided such as toilets, study rooms, health clinics, kitchens, blocks, offices, halls, library and water filter system. Those who have a family have been placed in family type blocks and the unmarried have been placed in different blocks where men and women were separated. In every block they stayed, names of donors were written. Moreover, a number of refugees were arranged to marry in Arakan mosque in August 29, 2015. They married in accordance with Islamic law for instance Omar Khaliq who married Senowara, Imam Hussein to Shomjida Begum, Hussain Ahmad to Bibi Jan, Mohammad Tuson to Zuleikha, and Kefayet to Nur Kolima.

Although Aceh was not their preferred destination, the they received so warm and incredible welcome from Acehnese and Aceh Government. They were not rejected by Acehnese, instead they were hugged. In North Aceh, the government had placed them in refuge shelters facilitated by local government, Aksi Cepat Tanggap (ACT), the United Nations High Commissioner for Refugees (UNHCR), International Organisation for Migration (IOM) and local and national nongovernment organisations (NGOs). Now, Rohingya refugees are being sheltered in North Aceh district, Indonesia. They have received freedoms enabling them to start a life (Grønlund, 2016) and they are well-protected.

\section{The Policy For Managing Rohingya Asylum Seekers}

Indonesian government initially thought about three alternatives in taking care of Rohingya issue, namely to return them to Myanmar, welcome them and provide them assistance or relocate them to other countries. The first alternative (to return the refugees to Myanmar) was not possible because the Myanmar government did not recognize them as the citizen of Myanmar. This alternative was also contradictory to the nonrefoulment principle as international law principle. It was not allowed to force back them to their homeland because it put their safety in danger. The second choice that was to welcome them temporarily, although was not easy to be done because they might not mingle with local people and in turn create social problems, was a good choice. It was because the third alternative, to relocate them into another country, would take a lot of processes and long time. From three difficult alternatives above, Indonesian government decided to take care of them in Indonesia for one year.
The Indonesian government decided to assist and manage the Rohingya refugees along with the international communities and the organization. They had to commit to give support, funding and durable solution. The government made this decision based on the principle of burden and responsibility sharing. The allocation of refuge shelters location had to take into consideration a social vulnerability that might arise during their one-year stay. It was clear that this case might involve transnational organised crime (TOC) so that procedures was strictly made and implemented and that the follow up actions had to be carried out carefully, especially by the Indonesian National Army, the Indonesian National Police and Immigration Department. The Coordinating Minister of Political, Legal and Security Affairs has assigned a task force focusing on human, refugee and asylum-seeker smuggling. The task force was established with a joint leadership of Indonesia, Malaysia and Thailand with the full support of the international community through UNHCR and IOM.

The change of Indonesian policy has smoothened the handling of Rohingya asylum seekers. It is one of the reasons why in the local level, the handling can be easily coordinated with the province government of Aceh and the district government of North Aceh. The Aceh Government represented by the Vice Governor Muzakir Manan showed serious intention to welcome Rohingya asylum seekers. The Aceh Government had shown a full commitment to help them in any Aceh territories, such as North Aceh, East Aceh and Langsa. These three places were under the authority of the district governments. The three locations had shelters which were taken care by the government of North Aceh, East Aceh and Langsa. This was the policy of the Aceh Government in handling the refugees and asylum seekers. In its operationalization, the treatment to them was handled by a number of NGOs and Islamic organization from Aceh and other provinces.

In North Aceh, the Vice Governor appreciated the work of the National Committee for Rohingya Solidarity (NCRS) with regards to their building of shelters and its management. Manan urged every institutions, organizations and volunteers who involved in handling Rohingya refugees to continue their works according to their job descriptions and capacities. To realize that idea, Manaf has coordinated with several heads of districts who managed shelters in their territories. The President of NCRS, Syuhelmaidi Syukur and the Executive Director of ACT, Sri Eddy Kuncoro agreed with his idea. They stated that the cooperation of all committed parties in NCRS was believed to continuously support the sustainability of integrated community shelter, especially the newly built facilities so that it could take some other refugees who were still staying in East Aceh and Langsa.

In the district level, the government of North Aceh has made official policy by permitting Rohingya asylum seekers to stay in their territory. The head of district has stated that they were welcomed and allowed to stay there and the government of North Aceh also has given social aids to them in the form of food, beverages, blankets, and medicine. This aid was an emergency step taken so that the refugees could survive in shelters (Interview with Jailaani, 2015).

However, some ministries in the provincial and local government have not involved actively in handling the 
refugees, such as the Religion Affairs Ministry of North Aceh branch. Having position as vertical institution, it only had a coordinating function. It was only involved in district forums (Interview with Marwan, the head of Islamic Counselling Unit of Religious Affairs Ministry of North Aceh, 2015). As a result, the religious counselling was not held although they had some $\mathrm{capable}$ counsellors. Instead, the religious counselling was held much by Daarut Tauhid and Insan TV (Interview with Muhar and Noni, 2015).

Similar to the Religious Affairs Ministry, North Aceh Representative Council was not institutionally invited to discuss the handling of the refugee issues. Even though, the council had budgeting right that could be used by the government to provide funding for the handling the refugees. They were not involved much because North Aceh still had low economic growth that it could not afford the funding. If the North Aceh government provided the refugees with shelters and other facilities there would be a serious social gap between them and the native people. (Interview with Anzir, 2015).

Such situation made, the North Aceh Government, Ulema Council Nahdlatul Ulama, local and national NGOs collaborate to handle the refugee issues. For example, Nahdlatul Ulama of the North Aceh branch intensively approached Ulema Council and NCRS to accept the asylum seekers provide them with trauma healing, education, and skill training.

\section{The Circulating Treatment Of Rohingya Refugees}

The assistive treatment to Rohingya refugees in North Aceh was not conducted only by a group or a community but involved many groups and organizations in the local, national and international level. It seemed there was labour division taking care of Rohingya asylum seekers in North Aceh. UNHCR gave aids not only to asylum seekers who left their home country to run away from violence and torture which endangered their freedom and life, but also to seekers who move from one region to another within a country; who don't have citizenship and who are willing to return to their homeland. The UNHCR attention was paid to vulnerable individuals such as women, widows, children under 18 years old, elderly people and the disabled. Along with its partners, UNHCR promoted several programs of protection and aid to ensure that their basic needs were fulfilled while they were waiting for comprehensive and viable long-term solution (Interview with Acha Rahardiansyah, Jailani and Teungku Risywan Ali Haji, 2015).

What the UNHCR did was assuring Rohingya asylum seekers to fulfill the registration of refugee status . After this registration, UNHCR assisted by competent interpreters conducted an interview. From this interview, their motives of fleeing their homeland could be assessed to decide whether the status of asylum seekers or refugees could be granted or not. These asylum seekers were then given one chance to file objection if their request of international protection was rejected (UNHCR, 2015).

In North Aceh, UNCHR in cooperation with IOM had already coped with the Rohingya asylum seekers problems.. Yet, the two could not handle this crisis by themselves because Rohingya had been an international issue which needed to be managed together, involving all country's components. A number of social groups, NGOs and Islamic organizations in Indonesia have tried to help them massively. This leads UNHCR and IOM to let them join in handling this issue in North Aceh and also in other regions of Aceh. Therefore, UNCHR duty is to assure the survivals of the Rohingya asylum seekers in North Aceh including creating and updating databases, checking their status and also giving safety assurance.

IOM's duties were to seek for international cooperation, to look for migration solution, to provide humanitarian assistance and to assure the good treatment towards them so that the asylum seekers rights were well protected. In North Aceh, IOM distributed logistic and health aids so that they could survive. The logistic aids that they received included food, beverages, bathing tools, and medicine.

NCRS has built shelters with adequate facilities (Integrated Community Shelter) in Blang Adoe, North Aceh. These shelters were funded by ACT and other donors and in turn every building has name of its donors. As an example, School for Rohingya's People was built by Al-Imdad Foundation and Humanitarian Relief Foundation, health clinics were built by Adara Relief International and Humanitarian Relief Foundation, water filter system was built by Putri Bungsu Foundation and The Red Cross of North Aceh and Arakan mosque was built by MTT.

In educational activities, NCRS and some local NGOs managed to conduct trainings and provide other educational services. Local English teachers, for example, taught the refugees English to help them to be able to communicate when they stay in other countries. (Yasin, Qismullah, Mawar, 2016). As English was very important for them, it was also taught in Arakan mosque and in some specially designed rooms in shelters every afternoon. ACT, Rumah Aceh and also Ikatan Pekerja Sosial Masyarakat had contributed to give them other educational services.

Another important aid was the trauma healing services done by Medicine Sans Frontier (MSF). This psychological healing was conducted in the refugee's room. They tried very hard to heal the trauma that they experienced in their homeland, in the boats or during their stay in the shelters. This was done to help them survive mentally as they were far away from their homeland; separated from their family; and not able to communicate with the local people in Indonesian or English.

The role of labour division in handling the asylum seekers in North Aceh can be seen from the circulation of local, national or international institutions which visited the Rohingya shelters, This showed that Rohingya asylum seekers were very welcomed by Indonesian society. The national policy seemed to be very helpful in handling the asylum seekers in Indonesia. This is a great contribution that North Aceh government, a number of NGOs, and other institutions has already done for this humanitarian crisis.

\section{CONCLUSION}

The Rohingya's Muslim asylum seekers in North Aceh have been protected by Indonesian government. Many local, ,national, international organizations also play an important role to support this policy. They are placed in refugee shelters facilitated by the local government, NCRS-ACT, UNHCR, 
IOM and other local and national NGOs. The protection of the Rohingya asylum seekers was the result of the collaboration of Indonesian government with international organisation and Indonesian civil society. This shows that the Indonesian government respects the international refugee law principles.

\section{REFERENCES}

[1] Mahmood. Syed S , Emily Wroe, Arlan Fuller, Jennifer Leaning. (2017). The Rohingya people of Myanmar: health, human rights, and identity. Volume 389, Issue 10081, May. 6-12.

[2] Pajic. Sofija, Magdalena Ulceluse, Gábor Kismihók, Stefan T. Mol, Deanne N. Den Hartog. (2017) Antecedents of job search self-efficacy of Syrian refugees in Greece and the Netherlands. Journal of Vocational Behavior, November, 6 .

[3] Nishiura. Hiroshi, Hyojung Lee, Baoyin Yuan, Akira Endo, Andrei R. Akhmetzhanov, Gerardo Chowell. (2017). Infectious disease risks among refugees from North Korea. International Journal of Infectious Diseases.

[4] Kampan. Palapan, Adam Richard Tanielian. (2017). Thailand's role in updating ASEAN immigration policy, Kasetsart Journal of Social Sciences Volume 38, Issue 3, September-December, 233-241.

[5] Cheung. Samuel. (2012).Migration Control and the Solutions Impasse in South and Southeast Asia: Implications from the Rohingya Experience'. Journal of Refugee Studies, Volume 25, Issue 1, March. 1, 50-70.

[6] Ullah. Akm Ahsan. (2011). Rohingya refugees to Bangladesh: historical exclusions and contemporary marginalization. Journal of Immigrant \& Refugee Studies Volume 9.

[7] Rahman. Utpala, (2010). The Rohingya refugee: a security dilemma for Bangladesh, Journal of Immigrant \& Refugee Studies.
[8] Kaur. Amarjit. (2007) Refugees and refugee policy in Malaysia, UNEAC Asia Papers No. 18

[9] Parnini. Syeda Naushin. (2013). The Burmese Question The Crisis of the Rohingya as a Muslim Minority in Myanmar and Bilateral Relations with Bangladesh. Journal of Muslim Minority Affairs Volume 33,

[10] Lim. Alvin Cheng-Hin. (2015). The 2015 refugee boat crisis in southeast Asia: humanitarian and security implications. June 18, 2015, http://www.eurasiareview.com

[11] Lewa. Chris. (2009). North Arakan: an open prison for the Rohingya in Burma. Forced Migration Review; Oxford.

[12] Singh. Bilveer, Asean (2014) Myanmar and the Rohingya issue. (2014). Himalayan and Central Asian Studies, New Delhi Vol. 18.

[13] Grønlund. Christine Alstad. (2016). Refugees in exodus: statelessness and identity: a case study of Rohingya refugees in Aceh, Indonesia, Master thesis development management, University of Agder.

[14] Thom. Graham. (2015). The May 2015 boat crisis: the Rohingya in Aceh, cosmopolitan civil societies. An Interdisciplinary Journal.

[15] Yasin. Burhanuddin, Yunisrina Qismullah Yusuf, Mawar Junita. (2016). Observing the culture barriers in the English classes at the Rohingya refugee camp in Aceh: preliminary findings. Proceedings of English Education International Conference, v. 1, n. 2

[16] Interview with Muhar and Noni, a staff in NCRS, 2015

[17] Interview with Acha Rahardiansyah, the Coordinator of Central Shelter for Rohingya, Interview with the Head of Social Unit, Jailani and Teungku Risywan Ali Haji, 2015.

[18] Interview with Anzir, member of of North Aceh Representative Council, 2015

[19] Interview with UNHCR staff, 2015

[20] Interview with IOM staff 